\title{
Microbial biofilms and their impact on medical areas: physiopathology, diagnosis and treatment
}

\author{
Silvestre Ortega-Peña ${ }^{1,2 *}$ and Edgar Hernández-Zamora ${ }^{3}$ \\ 1'Laboratorio de Infectología, Instituto Nacional de Rehabilitación Luis Guillermo Ibarra Ibarra; ${ }^{2}$ Departamento de Microbiología, Escuela Nacional \\ de Ciencias Biológicas, Instituto Politécnico Nacional; ${ }^{3}$ Servicio de Genética, Instituto Nacional de Rehabilitación Luis Guillermo Ibarra Ibarra. \\ Mexico City, Mexico
}

\begin{abstract}
Biofilms are communities of microorganisms that grow aggregated and surrounded by an extracellular matrix (EM), which they produce and favors them to adhere covalently to inert and living surfaces; it also helps them to develop a high tolerance to molecules with antimicrobial activity. Moreover, biofilms are associated with chronic and persistent infections, which negatively impact different medical areas since they generate high costs to health care systems and patients every year because they are difficult to treat with conventional antimicrobial drugs. Additionally, they generate high rates of morbidity and mortality. The objective of this review was to present extensive and up-to-date information on the origin, biosynthesis, and pathophysiology of biofilms. Also, its relationship with chronic infections, diagnosis, current antimicrobial treatments with antibiotic activity, and perspectives on the search for new treatments, since the latter still represent an important area of research.
\end{abstract}

Key words: Biofilms. Chronic infections. Antimicrobial tolerance. Diagnosis. Treatment.

\section{Biopelículas microbianas y su impacto en áreas médicas: fisiopatología, diagnóstico y tratamiento}

\section{Resumen}

Las biopelículas son comunidades de microorganismos que crecen agregados y rodeados por una matriz extracelular que ellos mismos producen, la cual favorece la adhesión covalente sobre superficies inertes y vivas; además, les ayuda a desarrollar alta tolerancia a las moléculas con actividad antimicrobiana. Por otra parte, las biopelículas se asocian con infecciones crónicas y persistentes que impactan de manera negativa en distintas áreas médicas. Además, generan altos costos a los sistemas de salud y a los pacientes cada año, porque son difíciles de tratar con antimicrobianos convencionales; adicionalmente, generan altas tasas de morbilidad y mortalidad. El objetivo de esta revisión es presentar información extensa y actualizada sobre el origen, la biosíntesis y la fisiopatología de las biopelículas, así como sobre su relación con infecciones crónicas, el diagnóstico, los tratamientos antimicrobianos actuales con actividad antibiopelícula y las perspectivas sobre la búsqueda de nuevos tratamientos. Estos últimos aún representan una importante área de investigación.

Palabras clave: Biopelículas. Infecciones crónicas. Tolerancia antimicrobiana. Diagnóstico. Tratamiento.

\section{Correspondence:}

*Silvestre Ortega Peña

E-mail: silvestreortega1265@gmail.com
Available online: 10-08-2018

Bol Med Hosp Infant Mex. 2018;75:67-75
www.bmhim.com

Bol Med Hosp Infant Mex. 2018;75:67-75
www.bmhim.com
Date of acceptance: 03-12-2017

DOI: 10.24875/BMHIME.M18000026

2444-3409/@ 2018. Hospital Infantil de México Federico Gómez, published by Permanyer México SA de CV, all rights reserved. 


\section{Introduction}

In microbiology, biofilms are defined as communities of microorganisms (mo) that grow aggregated and surrounded by an extracellular matrix (EM) that they produce. EM is composed of proteins, extracellular deoxyribonucleic acid (DNA) and exopolysaccharides (EPS) ${ }^{1}$. Due to the increase in scientific studies during the last three decades, biofilms have acquired great relevance, mainly in the medical area, since they facilitate the development of chronic infections such as otitis, osteomyelitis, wounds, among others, and also infections related to the use of medical devices, including intravascular catheters, joint prostheses, and urinary catheters ${ }^{2,3}$.

The treatment and eradication of infections caused by biofilm-producing mo represent a great challenge because they are more tolerant to the action of molecules with antimicrobial activity (antibiotics and antiseptics), in contrast to the mo that grow in free form (planktonic) $)^{4}$. Conversely, EM helps the microbial cells evade the host immune response; also, the EPS of the EM can induce chronic inflammatory responses ${ }^{5}$.

The objective of this review is to make a general description of biofilms, their origin, biosynthesis, and pathophysiology, as well as the relationship they have with chronic infections, diagnosis, treatment, and perspectives.

\section{The origin}

Biofilms were initially observed by Anton van Leeuwenhoek (1684) when he analyzed samples of microbial plaque obtained from his teeth ${ }^{6}$. Years later (1864), Louis Pasteur also saw them in samples collected from walls of the barrels where wine was stored; moreover, he proposed them to be the cause of the biotransformation of wine into acetic $\mathrm{acid}^{7}$. At the end of the 1980s, the biofilm definition had only been used in environmental microbiology, because its formation had been observed mainly in tubes which transported drinking water or in the lower part of boats. In medical microbiology, the concept of biofilms was utterly foreign; however, in 1985, Dr. John William Costerton (father of the Biofilmology) brought this concept to the medical area and proposed that many chronic infections could be caused by mo growing in the form of biofilms and that due to this characteristic patients did not respond to conventional antimicrobial treatments ${ }^{8}$.

Research on biofilms has exponentially increased in the last twenty years ${ }^{7,8}$. The first investigations aimed to discover and understand the genetic and molecular mechanisms that favor mo to growth in the form of biofilms, to know the EM chemical composition or to study the physiological, morphological, and biochemical changes that microbial cells undergo in biofilms ${ }^{8}$. The most recent studies are focused on studying the biofilms pathogenesis with in vitro and in vivo models $^{9,10}$.

\section{Biofilms biosynthesis}

From the discovery of biofilms to the present day, it is known that $90 \%$ of mo possess this microbiological characteristic and that their biosynthesis is a complex, constant, and dynamic process that occurs in four phases: adhesion, aggregation, maturation, and disintegration (Figure 1). In each of these phases, physicochemical forces and different genetic and molecular mechanisms that regulate the EM biosynthesis participate ${ }^{11}$.

During the adhesion phase, two phenomena occur that facilitate the mo to become deposited on a surface and to initiate the biofilm formation: attraction and adhesion $^{12,13}$. Attraction is a reversible process that occurs when mo, in a planktonic state, are attracted and deposited on inert surfaces by different types of physicochemical forces (Van der Waals, gravitational, electrostatic, hydrophobic or Brownian movements ${ }^{14}$ ). Physicochemical forces can belong to the microbial walls or the inert surfaces ${ }^{15}$. Once the microbial cells have been deposited on a surface, the adhesion phase, which is irreversible, immediately begins. The main components that produce microbial adhesion are constitutive molecules of the microbial wall: pili, flagella, teichoic acids or molecules that mo express under stress circumstances, which are called microbial surface components recognizing adhesive matrix molecules (MSCRAMMs) ${ }^{15-17}$. For instance, the adhesion of the different species of Staphylococcus spp. on different types of medical devices (intravascular catheters, heart valves or prostheses) occurs when the MSCRAMMs owned by these bacteria-accumulation-associated protein (AAP); biofilm-associated protein (Bap); autolysin (Atl) and extracellular matrix-binding protein (Embp)-are covalently bound to host EM proteins (fibronectin, fibrinogen, elastin, collagen), which coat medical devices immediately after they are implanted ${ }^{18-20}$.

After adhesion, aggregation begins, which occurs when more microbial cells are added to the mo that initially adhered ${ }^{18}$. During aggregation, high concentrations of secondary metabolites are generated, products 


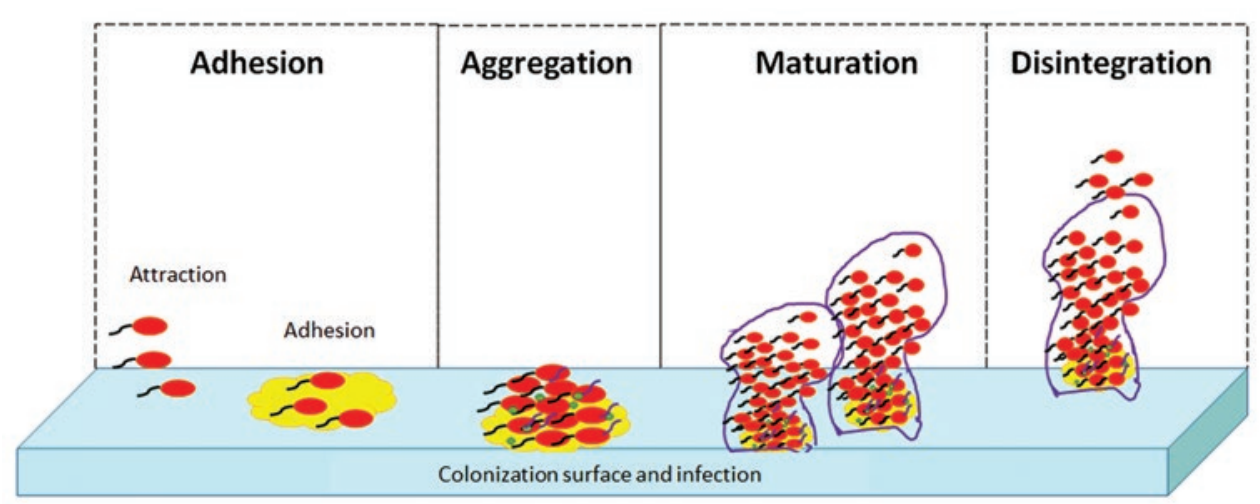

Figure 1. Biosynthesis process of microbial biofilms.

of microbial metabolism, which are used for microbial communication; the latter is called quorum sensing $(\mathrm{QS})^{21}$. The QS is a communication system possessed by bacteria that serves to induce or repress the expression of genes that encode virulence factors or enzymes involved in the biosynthesis of the EM main components, such as EPS and proteins ${ }^{22}$.

The third phase is maturation: in this phase, mo that have already been aggregated, start to multiply; in turn, there is an excessive production of EPS, proteins, and extracellular DNA release, which will help in the EM formation and the biofilm growth ${ }^{1}$. Several studies have shown that each bacterial species produces and releases specific EPSs that provide very diverse physiochemical properties to EM. For instance, Pseudomonas aeruginosa produces three different types of EPS: alginate, Pel, and Psl. In contrast, Staphylococcus spp. only produces the polysaccharide intercellular adhesin, also called poly-N-acetylglucosamine ${ }^{23,24}$.

In addition to the EPS secretion, another phenomenon that occurs in maturation is the release of extraceIlular DNA, which is useful for stiffening biofilms and participates in the transfer of resistance genes between mo that are found inside the biofilms ${ }^{25,26}$. Also, water channels are formed through and around the biofilms, which are important for the excretion and transport of QS molecules. They are also useful because they help mo to acquire nutrients from the external environment and eliminate products of microbial metabolism, which at some point may become cytotoxic to the mo themselves ${ }^{21,27}$. Equally important are other phenomena that take place during maturation like the morphological and metabolic changes suffered by the mo inside the biofilms ${ }^{21,22}$.
Disintegration is the last phase in the cycle of biofilm formation, and it occurs when the microbial density inside the biofilm has exponentially increased, generating significant amounts of metabolites which can no longer be eliminated through water channels. These metabolites induce QS, which in turn produces the expression of genes that encode enzymes that can degrade extracellular matrix components ${ }^{21}$.

Currently, it is known that degradation is controlled by enzymes with DNase, protease, phosphodiesterase activities and molecules with surfactant properties ${ }^{28}$. All these enzymes help small microbial aggregates or bacterial cells to detach from the EM and initiate biofilm formation on new surfaces ${ }^{29}$. In addition to the molecules that can degrade the biofilm EM, other molecules also disintegrate biofilms; for example, nitric oxide $(\mathrm{NO})^{30}$. In P. aeruginosa, NO produced by anaerobic respiration causes the disintegration of the biofilms formed by this bacterium, because NO decreases the intracellular concentration of a second messenger called cyclic di-GMP (c-di-GMP), which initiates a signaling system that regulates the behavior and lifestyle of many mo, making them change from a free form to biofilms or vice versa ${ }^{31,32}$. The role of $\mathrm{NO}$ in the disintegration of biofilms produced by clinically relevant mo apart from $P$. aeruginosa has also been studied (e.g., Neisseria gonorrhoeae, Neisseria meningitidis, Vibrio cholerae, Staphylococcus aureus, Legionella pneumophila, Escherichia coli, mainly $)^{30}$ and it has the same effect.

\section{Physiopathology}

Currently, it is known that the biofilm pathogenesis lies mainly in their capability of generating persistent 


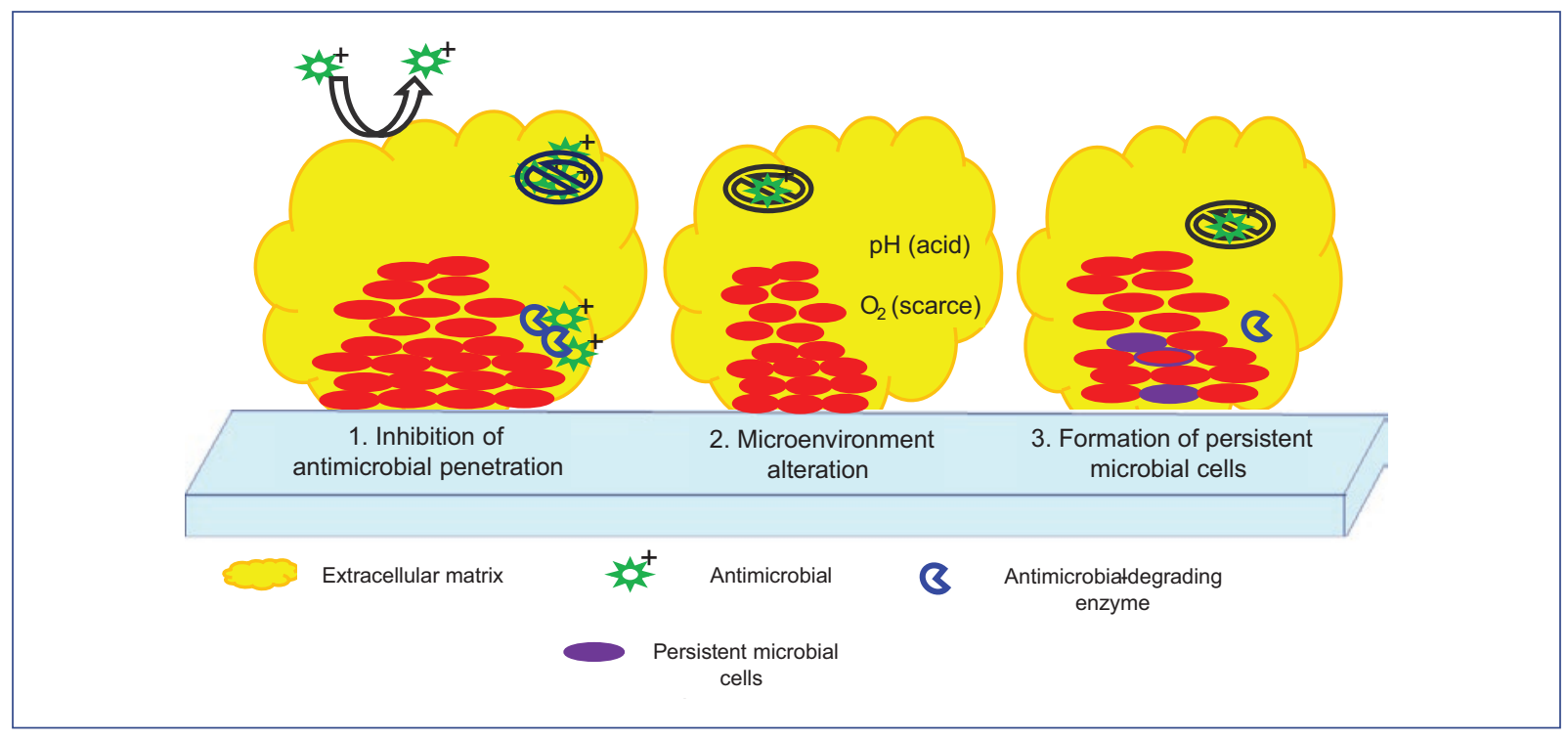

Figure 2. Phenomena that favor the development of antimicrobial tolerance.

chronic infections, which are difficult to eradicate ${ }^{1}$. This is due to the fact that mo that grow inside biofilms increase their tolerance to antimicrobial molecules (antibiotics and antiseptics) and develop mechanisms of resistance to antibiotics. Also, the EPS of the EM help to evade the host immune response ${ }^{2,4}$.

\section{Increase in antimicrobial tolerance}

It is known that mo grown in biofilms develop a high tolerance to antimicrobials up to a thousand times more than those that grow in free form ${ }^{4}$. This increase is mainly associated with the following phenomena: inhibition of antimicrobial penetration, microenvironment alteration and formation of persistent microbial cells (Figure 2).

\section{INHIBITION OF ANTIMICROBIAL PENETRATION}

Several studies have concluded that the physicochemical properties of the EM that surrounds the microbial cells can repel or delay the penetration of most of the antimicrobial agents currently marketed ${ }^{4,33}$. The repulsion or delay is explained by the differences in charges between the antimicrobials and the EM. For instance, aminoglycoside antibiotics that have a positive charge are trapped between the negative charges of the EPS in the $\mathrm{EM}^{34,35}$. In the case of antimicrobials that penetrate the EM, these same charge differences can delay the antimicrobial passage to the target site, causing the drugs to reach sub-inhibitory concentrations, which are capable of inducing stress responses in mo that favor the expression of antimicrobial resistance mechanisms (enzymes that degrade antibiotics, efflux pumps or target site alterations) and virulence factors (proteases, toxins, cytolysins) ${ }^{26,36}$.

\section{MicroenVIRONMENT ALTERATION}

In the biofilm most inner part, the oxygen concentration is low, which generates an anaerobic and low $\mathrm{pH}$ atmosphere. This can cause a decrease in the activity of some antibiotics, such as aminoglycosides, which diminish their effectiveness in anaerobic atmospheres $^{37,38}$. Other phenomena that occur due to microenvironment alterations are the decrease in both bacterial metabolism and time of replication ${ }^{37}$. It is important to remember that the goal of many antibiotics is to block metabolic pathways of mo, such as synthesis of proteins or the bacterial wall. For example, as there is a decrease in the time of replication, $\beta$-lactam antibiotics cannot act effectively ${ }^{37,39}$.

\section{FORMATION OF PERSISTENT MICROBIAL CELLS}

The increase in the antimicrobial tolerance of mo that are inside the biofilms cannot be explained only by the phenomena mentioned previously. In recent years, it has been reported that subgroups of mo with persistent cell phenotypes are formed within biofilms ${ }^{40}$. Persistent 


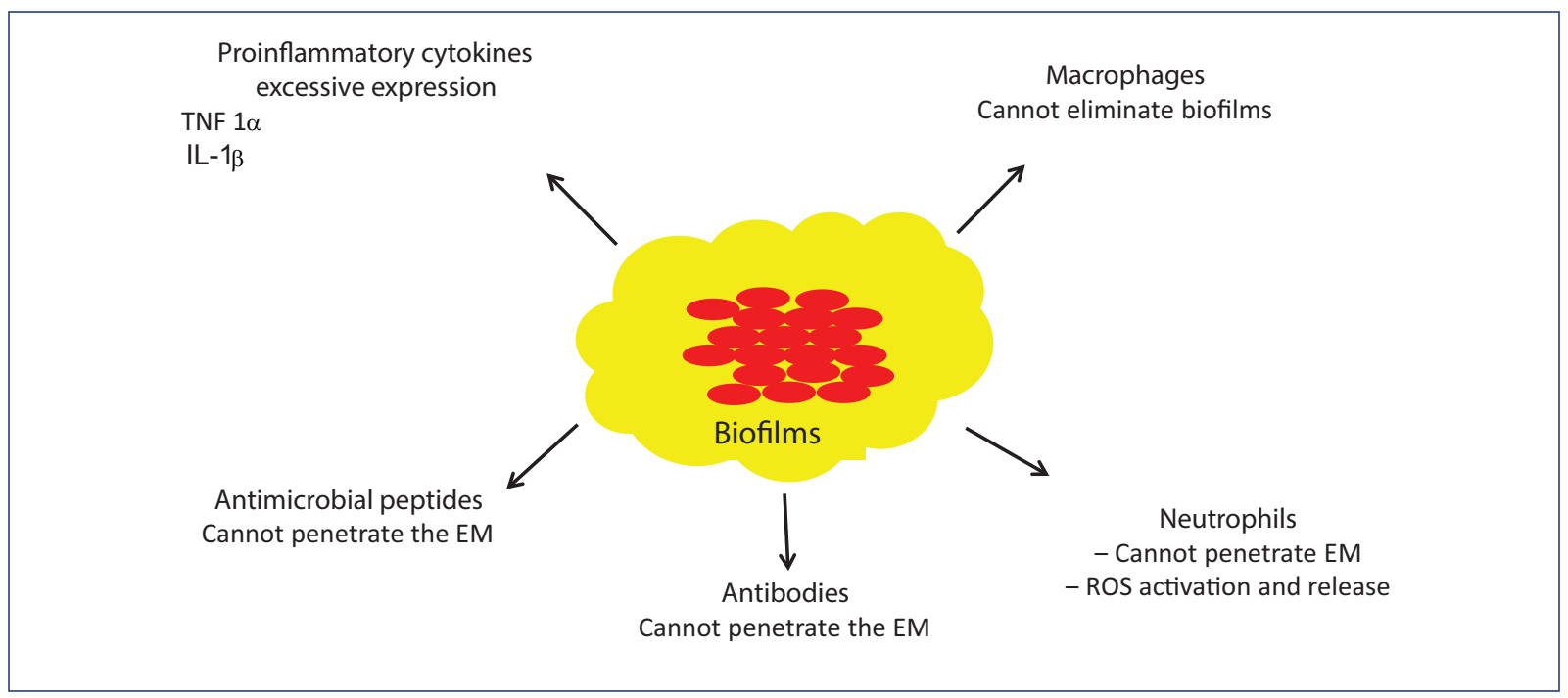

Figure 3. Biofilms and immune response components. EM: extracellular matrix; ROS: reactive oxygen species.

microbial cells are those that have an inactive metabolic state, in addition to undergoing morphological changes that prevent the action of antimicrobials ${ }^{40,41}$. The major problem of persistent mo is that they activate their metabolism again and migrate to another surface when the biofilms begin to disintegrate, starting the biosynthesis of biofilms again. Furthermore, persistent cells, before leaving biofilms, have developed antimicrobial resistance through different mechanisms (efflux pumps, degrading enzymes), so new biofilms will be formed with multidrug-resistant $\mathrm{mo}^{4,37,42}$.

\section{Inhibition of the immune response}

In addition to the antimicrobial tolerance increase, another phenomenon that occurs in infections caused by biofilm-producing mo is the ability to partially or entirely evade the immune response of the host (Figure 3$)^{43}$. Gil et al. demonstrated that the EPS and proteins of the EM could protect the bacteria against the cells and components of the immune response (neutrophils, macrophages, antibodies, antimicrobial peptides) in a murine model of $S$. aureus infection growing in the form of biofilms ${ }^{44}$. These same capacities have been observed with different types of mo and infection models, such as $P$. aeruginosa (cystic fibrosis), E. coli, and Proteus mirabilis (urinary tract infections). ${ }^{45,46}$ Another important finding of this research is that, depending on the EPS produced by mo, chronic inflammatory responses can be induced ${ }^{47}$. In an in vivo model in rabbits with infected wounds with two types of $P$. aeruginosa (a wild strain producing EPS and another mutant that did not produce EPS), Seth et al. demonstrated that the wild strain induced higher expression of proinflammatory cytokines: TNF- $1 \alpha$ and IL-1 $\beta$ compared to the mutant strain ${ }^{48}$. Exacerbation and prolongation of the expression of proinflammatory cytokines negatively affect the host, for example, causing a delay in the wound healing process when it is colonized with $P$. aeruginosa ${ }^{49}$.

\section{Infections associated with biofilms}

It has been found that chronic infections and biofilms are closely related. At the end of the seventies, Hoiby and Lam et al. described the colonization of $P$. aeruginosa growing as biofilms in the lungs of patients with cystic fibrosis (CF), which was one of the first infections associated with this microbiological characteristic ${ }^{50,51}$. When they analyzed lung biopsies of different CF cases, the authors demonstrated and observed that the bacteria were embedded as microaggregates in the tissues, which in turn were surrounded by $\mathrm{EM}^{50,51}$.

Years later, it was recognized that biofilms produced infections associated with the use of medical devices ${ }^{52}$. The first report of this topic dated from 1982 when a pacemaker of a patient with $S$. aureus infection was analyzed with scanning electron microscopy, where the infection was associated with the use of this medical device ${ }^{53}$. The microscopy results showed that bacteria were growing on the pacemaker in the form of biofil$\mathrm{ms}^{53}$. Since the first scientific evidence in which a 
relationship between infection and the biofilm formation was found, the list of infections has increased exponentially (Table 1$)^{37}$.

According to the literature, it is estimated that approximately $65 \%$ of all bacterial infections are caused by bacteria growing in the form of biofilms, which include those associated with medical devices and tissues. The incidence of changes depending on the site of infection. For example, an incidence of $2 \%$ is estimated in infections associated with breast implants; between $1-4 \%$, in joint prostheses; $4 \%$, in mechanical heart valves; $10 \%$, in ventricular shunt; $4 \%$, in pacemakers and defibrillators, and up to $80 \%$, in diabetic foot wounds ${ }^{54}$.

Furthermore, the types of biofilm producing mo that cause infections associated with medical implants and tissues also change. In infections caused by the presence of vascular catheters, the following mo are detected: Staphylococcus coagulase negative, S. aureus, $P$. aeruginosa, Enterobacter spp and Klebsiella spp. In contact lenses (rigid and soft): E. coli, P. aeruginosa, S. aureus, S. epidermidis, Candida spp. and Serratia spp. In native heart valves (endocarditis): Streptococcus spp, S. aureus, S. epidermidis, Bacillus spp and Enterococcus spp. In urinary catheters: E. coli, Enterococcus faecalis, $S$. epidermidis, $P$. aeruginosa, P. mirabilis, Klebsiella pneumoniae and other Gram-negative bacilli. In periodontitis: Fusobacterium nucleatum and Peptostretococcus anaerobius. Finally, in diabetic foot: anaerobic bacteria, fungi, $S$. aureus and $P$. aeruginosa ${ }^{37,54}$.

\section{Diagnosis}

\section{Biofilm detection}

There are several methodologies for biofilms detection; among them, those of microscopy (fluorescence, scanning electron, confocal laser), which allow biofilms to be observed directly on biopsies of infected tissues or contaminated medical devices ${ }^{55}$. However, these methods can be expensive or complex to perform. Therefore, their use will depend on the resources available to the laboratories where the diagnosis of infections associated with biofilms is made.

In the case of laboratories with scarce resources, phenotypic methods could be applied, which are much cheaper and easier to perform. These phenotypic methods include growth in 96-well microplates stained with crystal violet, tube method, and Congo Red Agar method ${ }^{56}$. The disadvantage of phenotypic methods is that it is not possible to directly identify the biofilms, but
Table 1. Infections related to biofilms.

\begin{tabular}{l|l}
\hline $\begin{array}{l}\text { Infections related to the use of } \\
\text { medical devices }\end{array}$ & Tissue infections \\
\hline - Ventricular shunt & - Chronic otitis media \\
- Contact lenses & - Chronic sinusitis \\
- Central vascular catheters & - Gingivitis \\
- Heart valves & - Chronic tonsillitis \\
- Pacemakers & - Chronic laryngitis \\
- Vascular graft & - Endocarditis \\
- Breast implants & - Cystic fibrosis \\
- Endotracheal tubes & - Kidney stones \\
- Urinary catheters & - Biliary tract infection \\
- Orthopedic implants & - Urinary tract infection \\
- Joint prostheses & - Osteomyelitis \\
& - Chronic wounds \\
\hline
\end{tabular}

only the mo that produces them; also, they are less sensitive and specific for biofilms detection compared to microscopy ${ }^{57}$.

\section{Sonication of medical devices}

When infections associated with medical devices are suspected, the sonication method may be used. This method consists of placing the device in a sterile container with a sterile physiological solution and then perform an ultrasonic bath at $40 \mathrm{kHz}$ for five minutes ${ }^{58}$. Subsequently, aliquots of the sonication liquid are taken and grown in enriched culture media ${ }^{58}$. In general, sonication allows the biofilms to be detached from medical devices and cultivate the mo that are causing the infection to identify them and perform antimicrobial sensitivity tests ${ }^{58}$. Of all the medical devices the intravascular catheters and the joint prostheses are the most used to cultivate biofilm-producing mo and diagnose infections associated with them by the sonication method $^{58,59}$.

In joint prosthesis infections (usually caused by microbial biofilms), microbiological diagnosis is traditionally made by culture of periprosthetic tissue samples (> 5 samples from different sites). However, several studies have shown that the specificity for identifying the mo that produce the infection is low compared to the sonication fluid culture obtained from the prosthesis $^{58}$. In a study published in 2017 by Van Diek et al., in which the methodologies mentioned above for the diagnosis of infections associated with joint prostheses were compared, the researchers found that the specificity of periprosthetic tissue culture was 0.80 (95\% confidence interval $(\mathrm{Cl})$ : $0.74-0.86)$, while the value in the prosthetic sonication liquid culture was higher, of $0.99(95 \% \mathrm{Cl}: 0.96-1)^{60}$. 


\section{Antimicrobial sensitivity assays}

Traditionally, antimicrobial sensitivity tests of pathogenic bacteria are carried out with one of the following methods: disk diffusion (Kirby-Bauer test) or minimum inhibitory concentration in broth (MIC) $)^{61}$. Disc diffusion and MIC are assays that have good sensitivity and specificity to determine the antimicrobial sensitivity of bacteria that grow in free form; however, for biofilm-growing $\mathrm{mo}$, the results cannot be extrapolated ${ }^{62}$. For the latter, it is important to mount antimicrobial susceptibility assays that allow determining the minimum biofilm inhibition concentration (MBIC) and the minimum biofilm eliminating concentration (MBEC), against which the antimicrobials act ${ }^{62}$. For example, Schmidt-Malan et al. evaluated the activity of tedizolid (a new antibiotic against multidrug-resistant Gram-positive bacteria) in Staphylococcus isolated from infections associated with a joint prosthesis, and found that the MIC at which the antibiotic killed $90 \%$ of the bacteria in a free state was $<0.5 \mu \mathrm{g} / \mathrm{ml} .^{63}$ However, when they determined in the same bacterial strains the concentration at which the antibiotic inhibited the biofilms formation (MBIC), it increased 1.5 times $(2 \mu \mathrm{g} / \mathrm{ml})$ to deplete the same percentage of bacteria $(90 \%)$. Finally, when the researchers induced the formation of biofilms in the Staphylococcus and determined the concentration at which tedizolid could eradicate $90 \%$ of the microbial cells growing in this state, they found an MBEC of $32 \mu \mathrm{g} / \mathrm{ml}$ (an increase of 31.5 times). In general, the $\mathrm{MBIC}$ determines the concentration at which antimicrobials can prevent mo from re-forming biofilms after being exposed to them, whereas MBEC serves to determine the concentration at which antimicrobials can eradicate well established and mature biofilms that have not been previously in contact with the antimicrobial $^{62,63}$.

\section{Treatments with anti-biofilm activity}

To the present date, the way to eradicate biofilms continues to represent a real challenge due to the physiological, metabolic and biochemical changes that mo acquire when they grow up surrounded by an EM. No antimicrobial treatment is specific to treat infections associated with biofilms. Of all the antimicrobial molecules that are currently used to control infections, only a few have been shown to have the ability to eradicate biofilms in vitro. Many of the results described so far on anti-biofilm activity are controversial since there are very few controlled clinical studies that support the results that
Table 2. Antibiotics and antiseptics (antimicrobials) with anti-biofilm activity.

\begin{tabular}{|c|c|c|}
\hline Antibiotics & Anti-biofilm & Reference \\
\hline Ampicillin & Yes & 67 \\
\hline Piperacillin & Yes & 68 \\
\hline Amoxicillin/clavulanic acid & Reduced & 69 \\
\hline Amikacin & Yes & 70 \\
\hline Gentamicin & Reduced & 68 \\
\hline Tobramycin & Reduced & 71 \\
\hline Ciprofloxacin & Yes & 67,68 \\
\hline Levofloxacin & Yes & 67 \\
\hline Ofloxacin & Yes & 68 \\
\hline Imipenem & Yes & 68 \\
\hline Cefotaxime & Reduced & 70 \\
\hline Oxacillin & Reduced & 70 \\
\hline Clarithromycin & Yes & 72 \\
\hline Vancomycin & Yes & 70 \\
\hline Daptomycin & Yes & 73 \\
\hline Rifampicin & Yes & 74 \\
\hline Fosfomycin & Yes & 69 \\
\hline \multicolumn{3}{|l|}{ Antiseptics } \\
\hline Silver & Yes & 64 \\
\hline Povidone-iodine & Reduced & 64 \\
\hline Cadexomer iodine & Yes & 64 \\
\hline Polyhexamethylene biguanide & Yes & 64 \\
\hline Chlorhexidine & Yes & 64 \\
\hline $\begin{array}{l}\text { Ethylenediaminetetraacetic } \\
\text { acid (EDTA) }\end{array}$ & Yes & 64 \\
\hline
\end{tabular}

have been obtained using in vitro studies ${ }^{64,65}$. Table 2 shows some antibiotics and antiseptics that have demonstrated good anti-biofilm activity in vitro. However, these agents must be used in a specific way, depending on the type of microorganism that is causing the infection, since it has been observed that antibiotics or antiseptics with anti-biofilm activity can lose this property against different biofilm-producing microbial species ${ }^{66-74}$. For example, amikacin has good anti-biofilm activity in $S$. aureus and $S$. epidermidis, but lower activity in $P$. aeruginosa. In the case of the antiseptic polyhexamethylene biguanide, Ortega et al. found a good anti-biofilm activity for Gram-positive bacteria (S. aureus and $S$. 
epidermidis), but a lower activity for Gram-negative bacteria (Acinetobacter baumannii, P. aeruginosa and K. pneumoniae, mainly) ${ }^{66}$. Conversely, several studies concluded that rifampicin and fosfomycin are the antibiotics having the best anti-biofilm activity. Therefore, in the case of antimicrobials with reduced anti-biofilm activity, it is advisable to make combinations with the antibiotics mentioned above to improve the anti-biofilm activity and optimize treatments ${ }^{64}$.

\section{Conclusions and perspectives}

During the last decades, information about the close relationship that exists between biofilms and infections, mainly chronic infections, has increased exponentially. As described above, the treatment of chronic infections caused by biofilm-producing mo continues to represent a significant challenge for clinicians, since no specific treatment with anti-biofilm activity exists currently. Most treatments designed to inhibit or eradicate biofilms show good results both in vitro and in vivo. However, when they have been tried to be extrapolated to the clinical practice, the results are not favorable, or the scientific evidence is not yet conclusive. For this reason, the design of antimicrobial treatments with anti-biofilm activity is an area of opportunity in research. With the current knowledge of the biofilm physiology, treatments acting in the different phases of the biofilm formation should be developed to eradicate persistent microbial cells. By this means, health systems could save the high economic costs generated by infections associated with biofilms, caused by hospitalization costs and prolonged antimicrobial treatments. Moreover, the use of these treatments would avoid the consequences that these types of infections can generate for patients.

\section{Ethical disclosures}

Protection of human and animal subjects. The authors declare that no experiments were performed on humans or animals for this study.

Confidentiality of data. The authors declare that they have followed the protocols of their work center on the publication of patient data.

Right to privacy and informed consent. The authors declare that no patient data appear in this article.

\section{Funding}

None.

\section{Conflicts of interest}

The authors declare no conflicts of interest.

\section{References}

1. Allewell NM. Introduction to biofilms thematic minireview series. J Biol Chem. 2016;291:12527-8.

2. Bjarnsholt T. The role of bacterial biofilms in chronic infections. APMIS Suppl. 2013:1-51.

3. Romanò CL, Romanò D, Morelli I, Drago L. The concept of biofilm-related implant malfunction and "low-grade infection". Adv Exp Med Biol. 2017:971:1-13.

4. Davies D. Understanding biofilm resistance to antibacterial agents. Nat Rev Drug Discov. 2003;2:114-22.

5. del Pozo JL, Patel R. The challenge of treating biofilm-associated bacterial infections. Clin Pharmacol Ther. 2007;82:204-9.

6. Slavkin HC. Biofilms, microbial ecology and Antoni van Leeuwenhoek. J Am Dent Assoc. 1997;128:492-5.

7. Høiby N. A personal history of research on microbial biofilms and biofilm infections. Pathog Dis. 2014;70:205-11.

8. Lappin-Scott H, Burton S, Stoodley P. Revealing a world of biofilms-the pioneering research of Bill Costerton. Nat Rev Microbiol. 2014;12:781-7.

9. Lawrence JR, Swerhone GD, Kuhlicke U, Neu TR. In situ evidence for metabolic and chemical microdomains in the structured polymer matrix of bacterial microcolonies. FEMS Microbiol Ecol. 2016;92.

10. Xiao J, Klein MI, Falsetta ML, Lu B, Delahunty CM, Yates III JR, et al. The exopolysaccharide matrix modulates the interaction between $3 \mathrm{D}$ architecture and virulence of a mixed-species oral biofilm. PLoS Pathog. 2012;8:e1002623.

11. Ortega Peña, Franco Cendejas R. Importancia médica del biofilm de Staphylococcus epidermidis en las infecciones de prótesis articular. Invest Discap. 2014;3:106-13.

12. Peters G, Locci R, Pulverer G. Adherence and growth of coagulase-negative staphylococci on surfaces of intravenous catheters. J Infect Dis. 1982;146:479-82.

13. Peters G, Locci R, Pulverer G. Microbial colonization of prosthetic devices. II. Scanning electron microscopy of naturally infected intravenous catheters. Zentralbl Bakteriol Mikrobiol Hyg B. 1981;173:293-9.

14. Grössner-Schreiber B, Teichmann J, Hannig M, Dörfer C, Wenderoth DF Ott SJ. Modified implant surfaces show different biofilm compositions under in vivo conditions. Clin Oral Implants Res. 2009;20:817-26.

15. Hook AL, Chang CY, Yang J, Atkinson S, Langer R, Anderson DG, et al. Discovery of novel materials with broad resistance to bacterial attachment using combinatorial polymer microarrays. Adv Mater. 2013; 25:2542-7.

16. Omali NB1, Zhu H, Zhao Z, Willcox MD. Protein deposition and its effect on bacterial adhesion to contact lenses. Optom Vis Sci. 2013;90:557-64.

17. Becker K, Heilmann C, Peters G. Coagulase-negative staphylococci. Clin Microbiol Rev. 201427:870-926.

18. Speziale P, Pietrocola G, Foster TJ, Geoghegan JA. Protein-based biofilm matrices in Staphylococci. Front Cell Infect Microbiol. 2014;4:171.

19. Pietrocola G, Nobile G, Gianotti V, Zapotoczna M, Foster TJ, Geoghegan JA, et al. Molecular interactions of human plasminogen with fibronectin-binding protein B (FnBPB), a fibrinogen/fibronectin-binding protein from Staphylococcus aureus. J Biol Chem. 2016;291:18148-62.

20. Buck AW, Fowler VG Jr, Yongsunthon R, Liu J, DiBartola AC, Que YA et al. Bonds between fibronectin and fibronectin-binding proteins on Staphylococcus aureus and Lactococcus lactis. Langmuir. 2010;26:10764-70.

21. Winzer K, Williams $P$. Quorum sensing and the regulation of virulence gene expression in pathogenic bacteria. Int J Med Microbiol. 2001; 291:131-43.

22. Qin X, Sun Q, Yang B, Pan X, He Y, Yang H. Quorum sensing influences phage infection efficiency via affecting cell population and physiological state. J Basic Microbiol. 2017;57:162-170.

23. Ryder C, Byrd M, Wozniak DJ. Role of polysaccharides in Pseudomonas aeruginosa biofilm development. Curr Opin Microbiol. 2007;10:644-8.

24. Campoccia D, Montanaro L, Ravaioli S, Pirini V, Cangini I, Arciola CR. Exopolysaccharide production by Staphylococcus epidermidis and its relationship with biofilm extracellular DNA. Int J Artif Organs. 2011; 34:832-9.

25. Montanaro L, Poggi A, Visai L, Ravaioli S, Campoccia D, Speziale P, et al. Extracellular DNA in biofilms. Int J Artif Organs. 2011;34:824-31.

26. Flemming $\mathrm{HC}$, Wingender J. The biofilm matrix. Nat Rev Microbiol. 2010;8:623-33.

27. Guimerà X, Dorado AD, Bonsfills A, Gabriel G, Gabriel D, Gamisans X. Dynamic characterization of external and internal mass transport in heterotrophic biofilms from microsensors measurements. Water Res. 2016;102:551-60. 


\section{S. Ortega-Peña, E. Hernández-Zamora: Microbial biofilms in medicine}

28. Uppuluri P, Lopez-Ribot JL. Go forth and colonize: dispersal from clinically important microbial biofilms. PLoS Pathog. 2016;12:e1005397.

29. Cheung GYC, Hwang-Soo J, Chatterjee SS, Otto M. Phenol-soluble modulins-critical determinants of staphylococcal virulence. FEMS Microbiol Rev. 2014;38:698-719.

30. Barraud N, Kelso MJ, Rice SA, Kjelleberg S. Nitric oxide: a key mediator of biofilm dispersal with applications in infectious diseases. Curr Pharm Des. 2015;21:31-42.

31. Kim SK, Lee JH. Biofilm dispersion in Pseudomonas aeruginosa. J Microbiol. 2016;54:71-85.

32. Jenal U, Reinders A, Lori C. Cyclic di-GMP: second messenger extraordinaire. Nat Rev Microbiol. 2017;15:271-284.

33. Stewart PS. Diffusion in biofilms. J Bacteriol. 2003;185:1485-91.

34. Gordon CA, Hodges NA, Marriott C. Antibiotic interaction and diffusion through alginate and exopolysaccharide of cystic fibrosis-derived Pseudomonas aeruginosa. J Antimicrob Chemother. 1988;22:667-74.

35. Nichols WW, Dorrington SM, Slack MP, Walmsley HL. Inhibition of tobramycin diffusion by binding to alginate. Antimicrob Agents Chemother. 1988:32:518-23

36. Stewart PS. Antimicrobial tolerance in biofilms. Microbiol Spectr. 2015;3.

37. Lebeaux D, Ghigo JM, Beloin C. Biofilm-related infections: bridging the gap between clinical management and fundamental aspects of recalcitrance toward antibiotics. Microbiol Mol Biol Rev. 2014;78:510-43.

38. Stewart PS, Franklin MJ. Physiological heterogeneity in biofilms. Nat Rev Microbiol. 2008:6:199-210.

39. Ashby MJ, Neale JE, Knott SJ, Critchley IA. Effect of antibiotics on nongrowing planktonic cells and biofilms of Escherichia coli. J Antimicrob Chemother. 1994:33:443-52.

40. Kussell E, Kishony R, Balaban NQ, Leibler S. Bacterial persistence: a model of survival in changing environments. Genetics. 2005;169:1807-14

41. Allison KR, Brynildsen MP, Collins JJ. Metabolite-enabled eradication of bacterial persisters by aminoglycosides. Nature. 2011:473:216-20.

42. Strugeon E, Tilloy V1, Ploy MC1, Da Re S. The stringent response promotes antibiotic resistance dissemination by regulating integron integrase expression in biofilms. mBio. 2016;7:e00868-16.

43. Watters C, Fleming D, Bishop D, Rumbaugh KP. Host responses to biofilm. Prog Mol Biol Transl Sci. 2016;142:193-239.

44. Gil C, Solano C, Burgui S, Latasa C, García B, Toledo-Arana A, et al. Biofilm matrix exoproteins induce a protective immune response against Staphylococcus aureus biofilm infection. Infect Immun. 2014;82:1017-29.

45. Alhede M, Bjarnsholt T, Givskov M, Alhede M. Pseudomonas aeruginosa biofilms: mechanisms of immune evasion. Adv Appl Microbiol. 2014:86:1-40.

46. Mauch RM, Jensen PØ, Moser C, Levy CE, Høiby N. Mechanisms of humoral immune response against Pseudomonas aeruginosa biofilm infection in cystic fibrosis. J Cyst Fibros. 2017; pii: S1569-1993:30875-5. doi: 10.1016/j.jcf.2017.08.012.

47. Clinton A, Carter T. Chronic wound biofilms: pathogenesis and potential therapies. Lab Med. 2015;46:277-84.

48. Seth AK, Geringer MR, Galiano RD, Leung KP, Mustoe TA, Hong SJ. Quantitative comparison and analysis of species-specific wound biofilm virulence using an in vivo, rabbit-ear model. J Am Coll Surg. 2012 215:388-99.

49. Scalise A, Bianchi A, Tartaglione C, Bolletta E, Pierangeli M, Torresetti M et al. Microenvironment and microbiology of skin wounds: the role of bacterial biofilms and related factors. Semin Vasc Surg. 2015;28:151-9.

50. Hoiby N. Pseudomonas aeruginosa infection in cystic fibrosis. Diagnostic and prognostic significance of Pseudomonas aeruginosa precipitins determined by means of crossed immunoelectrophoresis. Scand J Respir Dis. 1977:58:65-79.

51. Lam J, Chan R, Lam K, Costerton JW. Production of mucoid microcolonies by Pseudomonas aeruginosa within infected lungs in cystic fibrosis. Infect Immun. 1980;28:546-56.

52. Lebeaux D, Chauhan A, Rendueles O, Beloin C. From in vitro to in vivo models of bacterial biofilm-related infections. Pathogens. 2013;2:288-356.

53. Marrie TJ, Nelligan J, Costerton JW. A scanning and transmission electron microscopic study of an infected endocardial pacemaker lead. Circulation. 1982:66:1339-41.
54. Jamal M, Ahmad W, Andleeb S, Jalil F, Imran M, Nawaz MA, et al. Bacterial biofilm and associated infections. J Chin Med Assoc. 2018; 81:7-11.

55. Gompelman M, van Asten SA, Peters EJ. Update on the role of infection and biofilms in wound healing: pathophysiology and treatment. Plast Reconstr Surg. 2016;138:61S-70S.

56. Hassan A, Usman J, Kaleem F, Omair M, Khalid A, Iqbal M. Evaluation of different detection methods of biofilm formation in the clinical isolates. Braz J Infect Dis. 2011;15:305-11.

57. Mishra SK, Basukala P, Basukala O, Parajuli K, Pokhrel BM, Rijal BP. Detection of biofilm production and antibiotic resistance pattern in clinical isolates from indwelling medical devices. Curr Microbiol. 2015;70:128-34.

58. Martinez RM, Bowen TR, Foltzer MA. Prosthetic device infections. Microbiol Spectr. 2016;4

59. Pérez-Zárate P, Aragón-Piña A, Soria-Guerra RE, González-Amaro AM, Pérez-Urizar J, Pérez-González LF, et al. Risk factors and biofilm detection on central venous catheters of patients attended at a tertiary hospital. Micron. 2015;78:33-9

60. Van Diek FM, Albers CGM, Van Hooff ML, Meis JF, Goosen JHM. Low sensitivity of implant sonication when screening for infection in revision surgery. Acta Orthop. 2017;88:294-99.

61. Clinical and Laboratory Standards Institute. Performance for antimicrobial susceptibility testing; Twenty-fifth informational supplement. CLSI document M100-S25. Wayne: Clinical and Laboratory Standards Institute, 2016

62. Girard LP, Ceri H, Gibb AP, Olson M, Sepandj F. MIC versus MBEC to determine the antibiotic sensitivity of Staphylococcus aureus in peritoneal dialysis peritonitis. Perit Dial Int. 2010;30:652-6.

63. Schmidt-Malan SM, Greenwood Quaintance KE, Karau MJ, Patel R. In vitro activity of tedizolid against staphylococci isolated from prosthetic joint infections. Diagn Microbiol Infect Dis. 2016;85:77-9.

64. Percival SL, Finnegan S, Donelli G, Vuotto C, Rimmer S, Lipsky BA. Antiseptics for treating infected wounds: Efficacy on biofilms and effect of $\mathrm{pH}$. Crit Rev Microbiol. 2016;42:293-309.

65. Percival SL, McCarty S, Hunt JA, Woods EJ. The effects of $\mathrm{pH}$ on wound healing, biofilms, and antimicrobial efficacy. Wound Repair Regen. 2014; 22:174-86.

66. Ortega-Peña S, Hidalgo-González C, Robson MC, Krötzsch E. In vitro microbicidal, anti-biofilm and cytotoxic effects of different commercial antiseptics. Int Wound J. 2017:14:470-9.

67. Anderl JN, Franklin MJ, Stewart PS. Role of antibiotic penetration limitation in Klebsiella pneumoniae biofilm resistance to ampicillin and ciprofloxacin. Antimicrob Agents Chemother. 2000;44:1818-24.

68. Shigeta M, Komatsuzawa H, Sugai M, Suginaka H, Usui T. Effect of the growth rate of Pseudomonas aeruginosa biofilms on the susceptibility to antimicrobial agents. Chemotherapy. 1997:43:137-41.

69. Rodríguez-Martínez JM, Ballesta S, Pascual A. Activity and penetration of fosfomycin, ciprofloxacin, amoxicillin/clavulanic acid and co-trimoxazole in Escherichia coli and Pseudomonas aeruginosa biofilms. Int J Antimicrob Agents. 2007;30:366-8.

70. Singh R, Ray P, Das A, Sharma M. Penetration of antibiotics through Staphylococcus aureus and Staphylococcus epidermidis biofilms. J Antimicrob Chemother. 2010:65:1955-8.

71. Walters MC $3^{\text {rd }}$, Roe F, Bugnicourt A, Franklin MJ, Stewart PS. Contributions of antibiotic penetration, oxygen limitation, and low metabolic activity to tolerance of Pseudomonas aeruginosa biofilms to ciprofloxacin and tobramycin. Antimicrob Agents Chemother. 2003;47:317-23.

72. Yasuda H, Ajiki Y, Koga T, Kawada H, Yokota T. Interaction between biofilms formed by Pseudomonas aeruginosa and clarithromycin. Antimicrob Agents Chemother. 1993;37:1749-55

73. Stewart PS, Davison WM, Steenbergen JN. Daptomycin rapidly penetrates a Staphylococcus epidermidis biofilm. Antimicrob Agents Chemother. 2009;53:3505-7.

74. Dunne WM Jr, Mason EO Jr, Kaplan SL. Diffusion of rifampin and vancomycin through a Staphylococcus epidermidis biofilm. Antimicrob Agents Chemother. 1993;37:2522-6. 